stances nor with the supraspinatus ligament of the vertebral column. The Corneal Grafting Act became law in 1952, not ten years before. But these are trifling matters in a book so packed with interest and good judgement. Lucid accounts are given of such subjects as erysipeloid, intracranial thrombophlebitis, poliomyelitis and the treatment of alcoholism with antabuse; specialist in nature but of considerable general interest. This perhaps is the reason for the continued success of the Medical Annual, that it presents for all of us that which might otherwise only be known to some.

H.H.G.E.

\section{THE SPINAL CORD}

\section{A CIBA FOUNDATION SYMPOSIUM}

Edited by J. L. Malcolm, M.B., Ch.B., D.Med.Sc., J. A. B. GraY, M.D., M.B., B.Ch., and G. E. W. Wolstenholme, O.B.E., M.A., M.B., B.Ch. Pp. xii +300 , with I I 2 illustrations. London: J. \& A. Churchill Ltd., r953. 30s.

'The Spinal Cord' is the fifth of the books so far published, containing the papers and discussion of the various international symposia arranged by the Ciba Foundation.

The reader who is not familiar with the field of neurophysiology will find it a difficult book to read but this does not mean to say that it has no interest for the clinician. Donal Brooks' paper in particular, 'Nerve Conduction in Poliomyelitis,' has considerable clinical importance. Brooks describes investigations on the conduction properties of superficially situated nerves supplying muscles which are, to clinical testing, completely paralysed by poliomyelitis. These investigations were aimed at obtaining progniostic information but they revealed several important anomalies of nerve conduction. The discussion of these anomalies at the symposium illustrates the value of joint discussion by physiologists and clinicians and is of importance to anyone working on poliomyelitis.

Other papers of clinical interest include K. E. Hagbarth's description of both inhibitory and excitatory effects from stimulation of different skin areas in the hindlimb ("Specific Skin Areas for Excitation and Inhibition of Hind Limb Reflexes ') and C. B. B. Downman's contribution, - Some Features of the Spinal Reflex Connections of Splanchnic Afferent Fibres.' The latter paper discusses the nature of the protective reflex contraction of intercostal and abdominal muscles in response to.splanchnic nerve stimulation.

Of particular interest to the neurophysiologist are the papers by Eccles et al. on 'Antidromic Propagation of Impulses into Motoneurones,' and by Lorente de Nó on 'Conduction of Impulses in the Neurones of the Oculomotor Nucleus.'

Those who believe in the sterility of cybernetic interpretations of neurophysiological phenomena will find nothing in the paper of P. A. Merton, 'Speculations on the Servo-Control of Movement,' to make them change their views.

A.M.
HISTOCHEMISTRY, THEORETICAL AND APPLIED

By A. G. Everson Pearse, M.A., M.D. Pp. viii + 530, with II9 illustrations +4 colour plates. London: J. \& A. Churchill, Ltd. 1953. £3.

Microscopic histochemistry is a science of botanical origin dating from the r 820's and now enjoying a vigorous revival in the field of human pathology. Its object is to demonstrate by refined chemical procedures the nature and function of cells and their products. In this way, for example, the gonadotrophic function of the basophil cells of the pituitary gland can be shown with remarkable clarity and the high concentration of cholinesterase in normal motor end-plates can be compared with those found after nerve-section. Here is the sort of problem which can be resolved by histochemical methods. Biochemical analysis of a sample of kidney will show a certain concentration of alkaline phosphatase. Where does it come from? Phosphatase, however, can hydrolyse naphthyl phosphate and the free naphthol can be made to form an insoluble azo dye which remains at the site of enzyme activity. In this way the enzyme in the kidney is shown to come from the brush border of the convoluted tubules.

Dr. Everson Pearse, who has made a special study of histochemical methods at the PostGraduate Medical School, has now written his ex? perience in this field and has brought together ald the methods he has thoroughly proved in practice? It is the first book of its kind from a British author and for comparison one must go to Lison of Belgium and to Gomori of the United States. It has been beautifully produced by Messrs. Churchill and is freely illustrated. A bibliography of nearly 2,000 selected references is a valuable feature, while the index runs to not less than 36 pages. The colour blocks are so excellent that one could wish for more.

This book has gained immediate and welldeserved popularity with laboratory workers all over the world, so much so that a second printing has already been called for. If subsequent editions are compiled with the same critical care, the book will surely establish itself as a standard work of reference.

K.I.N.

\section{JOURNAL OF FORENSIC MEDICINE}

This new journal published in Cape Town is designed to fulfil an international need. It will confine its scope to the medico-legal field and will devote its pages to case reports, reviews, abstracts, medico-legal news and the publication of original research work in this increasingly important branch of knowledge and practice.

Published quarterly by:

Juta \& Co. Ltd., P.O. Box 30, Cape Town.

Annual subscription, $£_{2} 2$ s. 